\title{
The Competitive Advantage of Collaboration - Throwing New Light on The Nordic Model
}

Atle Midttun ${ }^{1}$ and Nina Witoszek ${ }^{2}$

\section{ABSTRACT}

In one of the most influential contributions to modern political economy, Hall and Soskice have launched a distinction between 'liberal' and 'coordinated' market economies, placing the Nordic countries firmly in the latter category. We argue that, while the H\&S distinction may serve classificatory purposes, seeing the Nordic model in terms of 'coordinated capitalism' blurs the distinctive features of the Nordic countries' success as productive and fair economies. We contend that the central formula behind this success lies in what we call the Nordic model's ambidexterity the capacity to combine collaborative and competitive elements and skilfully navigate between them. Using an interdisciplinary perspective (inspired by organisation theory, cultural semiotics and evolutionary analysis), we provide a conceptual basis for reinterpreting the Nordic Model as an ambidextrous combination of culturally rooted, collaborative strategies that are subsequently competitively exposed.

The article illustrates the workings of this ambidexterity in three societal domains: work life (including female participation), resource management - illustrated by the Norwegian petroeconomy - and international business management and regulation with a focus on CSR. In each case we will show how collaboration is intertwined with pragmatic competitive exposure, yielding high productivity, high welfare, as well as fair income and wealth distribution.

\section{The Competitive Advantage of Collaboration (Introduction)}

In the twenty-first century, Norway, Denmark and Sweden remain icons of fair societies, with high economic productivity, fair income and wealth distribution, and high quality of life. Having moved beyond civil and political rights to also include extended social rights, they provide their citizens with a broad set of public services, including free health care and schooling at all levels. But they also combine social inclusion with competitive engagement in international markets. The 'Nordic model' has therefore been a point of fascination to scholars on the democratic left (e.g. Barth et al. 2015, Krugman 2015, Stiglitz 2015) and liberal political scientists such as Fukuyama (2011).

In the prevalent typologies dominant in political economy, the Nordics have traditionally been depicted as polar opposites to liberal market economies: as 'neocorporatist' (Schmitter and Streeck 1982), as examples of 'democratic capitalism' (Sejersted 2011), or as 'coordinated market economies' (Hall and Soskice 2001). While these labels, and the corresponding theoretical approaches, have shed light on some of the peculiarities of the Nordic model, they tend to highlight the democratic-communitarian- regulatory nexus and neglect the dynamic, competitive aspects of the Nordics (Witoszek and Midttun 2018).

\footnotetext{
${ }^{1}$ BI Norwegian Business School, Oslo, Norway

${ }^{2}$ Centre for Development and the Environment, University of Oslo
} 
As we will show, the Nordic delivery of both inclusive fairness and competitive productivity does not only happen by embracing a cooperative and regulatory ethos but is the result of skilfully navigating between cooperative and competitive strategies. To take H\&S's typology as a point of departure, we contend that while Nordic countries show hallmarks of being 'coordinated market economies' (CMEs) in some domains (e.g. welfare provision, work-life regulation, etc.), they are equally examples of 'liberal market economies' (LMEs) in other domains: (competitive exposure, business freedom, etc.). We argue that in order to understand the seemingly paradoxical nature of the Nordic political economy, it is more fruitful to draw on the concept of ambidexterity, inspired byO'Reilly and Tushman's work in innovation-oriented organisation theory (O'Reilly and Tushman 2004), which allows the Nordics to combine collaborative and competitive elements and skilfully manoeuvre between them. That said, their successful mix of collaboration and competition relies on differentiation, or what evolutionary thinkers would term 'multilevel selection'. At one level, or in one domain, the Nordic countries collaborate, at another level they compete, using their collaborative teamwork as a strategic asset.

The effective ambidexterity Nordic style presupposes high collaborative capacity. This capacity is not, as is often held, solely a 'specialty' of the labour movement or the result of strong trade unions and employers' organisations. We argue that equally - if not more - important are deeply entrenched cultural and religious norms and values (habitus), which more often than not have been occluded from political and economic analysis ${ }^{3}$. The trade unions, in particular, have been studied as drivers of social cooperation and solidarity. We hold that it is a broader and shared, normative founding tradition - rooted in the ideals of the Nordic Christian Enlightenment - that is essential to unwrapping the sustainability of the Nordic model and its resilience under stress.

\section{Theoretical and Methodological Approaches (Materials and Methods)}

\section{Theoretical Underpinnings}

Our reconceptualization of the Nordic model in terms of ambidexterity at different levels has been prompted by three inspirations. The first is O'Reilly and Tushman's (2004) idea of the ambidextrous organisation, which responds to the dilemma of melding efficient production with creative innovation at the firm level. This organisational structure - granting autonomy to production and the innovation process - both shields regular production from creative destruction and, at the same time, promotes new thinking and techniques.

The second inspiration in our approach comes from the so-called third wave of evolutionary iology that has focused on how collaborative behaviour may carry equal, if not stronger, weight than competition in forging resilience and adaptability (Wilson and Wilson 2007). This position is opposed to the often crude and simplified Darwinism associated with the 'survival of the fittest'. Rather, it draws attention to the balance of collaboration and competition - i.e. the collaborating group needs to be competitively exposed at a higher level in order to maintain its productivity. The evolutionary principle of multilevel selection is a helpful heuristic tool in the sense that it indicates that a selection at one level can be dependent on collaboration, while at another level it can be competitive. Following this reading, increased resilience and adaptation can be achieved by combining competitive and collaborative selection at different levels and in different domains.

Last but not least, the study builds on historical semiotic studies of the Nordic model (Witoszek 1998, 2011), which have highlighted the paramount role of enduring cultural values and practices

\footnotetext{
${ }^{3}$ There are some exceptions, e.g. the work of Mjøset (2011) and Sejersted (2011).
} 
that have been replicated through cultural texts and symbolic forms from generation to generation. These values and beliefs - disseminated via schooling and fuelling peasant and labour movements have played a decisive role in maintaining the robustness of the Nordic model in the face of ever new challenges.

We argue that Nordic ambidexterity is implemented through an interplay between competition and collaboration at various micro, meso and macro levels. As an ideal type, this ambidextrous model may be contrasted with the neoliberal model, which features a simple alignment of competition all the way through, from the micro through the meso to the macro level. It also differs from planned economy model, which assumes planned co-ordination at and between all levels (Table 1 ).

Our claim is that, at its best, the Nordic model - with its pragmatic ambidextrous combination of markets and collaborative behaviour at different levels - has fostered a competitive advantage of collaboration. This stands in contrast to the neoliberal argument for the competitive advantage of pure competition, and planned economy arguments for the advantage of pure planned coordination.

Our approach refines and nuances Hall and Soskice's influential work on the Varieties of Capitalism, and their distinction between LMEs and CMEs (H\&S 2001). While H\&S lock the Nordics into the CME ideal type, we hold that this classification of the political economy of the Nordic model is misleading by neglecting its navigation between the two ideal types. On the one hand, Nordic market conomies are highly competitive, and in many respects fit more under the LME label than the CME description. They have been early deregulators of a number of sectors, such as electricity markets, telecommarkets and housing markets, and have stock exchanges working under international standards. The transparency of their regulation contributes to competitiveness and they are generally champions of multilateral trade agreements and open international markets, all hallmarks of LMEs. At the same time, however, they are capable of strong collaborative action in other domains, such as welfare provision, education, or working life regulation, where CME characteristics more appropriately apply.

The dualist essence of the Nordic political economy is captured in the report of the US Council of Economic Advisers (COEA 2018) on the Opportunity Costs of Socialism. While the report is highly critical of the 'collaborative' sides of Nordic 'socialism', its authors admit that the Nordic countries are, in important respects, more liberalist than the USA - the LME protagonist in H\&S's analysis:

"...Nordic taxation overall is surprisingly less progressive than U.S. taxes. The Nordic countries also tax capital income less and regulate product markets less than the United States does."

Even the Heritage Foundation ranks the Nordic economies higher than the United States for business freedom (Miller et al. 2018). Furthermore, the OECD considers all five Nordic countries as having less product-market regulation than the United States (OECD, quoted in COEA 2018, Table 4). Taking the above into consideration, our approach based on ambidexterity and multilevel selection provides us with better tools to capture the uniqueness of the Nordic productive dualism. Rather than representing the CME type, the Nordic Model is successful in large part because it overcomes the LME-CME divide.

Some studies of the Nordics in the VOC tradition typically go into a richer but more descriptive mode that transcends the VOC typology. Thus, Mjøset (2011) in The Nordic Varieties of Capitalism presents a rich portrayal of core elements of Finnish, Danish, Swedish and Norwegian political economy, but without adding much conceptual refinement to the VOC model (Schwartz 2013). Similarly, Hull 
Kristensen and Lilja (2011) have edited a series of case studies of Nordic business successes, documenting how their achievement is a fortuitous end product of several, sometimes unrelated,

Table 1: Modes of Social Organisation in a Multilevel Selection Perspective

\begin{tabular}{|c|c|c|c|c|c|c|}
\hline & NEOLIBER & & PLANNED & & AMBIDEXTR & \\
\hline $\begin{array}{l}\text { Selection } \\
\text { level }\end{array}$ & $\begin{array}{l}\text { Selection } \\
\text { mode }\end{array}$ & \multirow{4}{*}{ 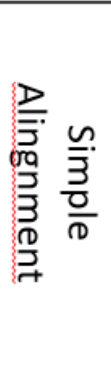 } & $\begin{array}{l}\text { Selection } \\
\text { mode }\end{array}$ & \multirow{4}{*}{ 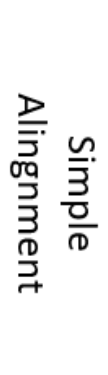 } & $\begin{array}{l}\text { Selection } \\
\text { mode }\end{array}$ & \multirow{4}{*}{ 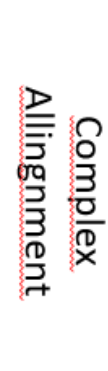 } \\
\hline $\begin{array}{l}\text { Higher } \\
\text { level }\end{array}$ & Competitive & & $\begin{array}{l}\text { Coordinated/ } \\
\text { Collaborative }\end{array}$ & & Competitive & \\
\hline $\begin{array}{l}\text { Meso } \\
\text { level }\end{array}$ & Competitive & & $\begin{array}{l}\text { Coordinated/ } \\
\text { Collaborative }\end{array}$ & & $\begin{array}{l}\text { Collaborative/ } \\
\text { Coordinated }\end{array}$ & \\
\hline $\begin{array}{l}\text { Lower } \\
\text { level }\end{array}$ & Competitive & & $\begin{array}{l}\text { Coordinated/ } \\
\text { Collaborative }\end{array}$ & & $\begin{array}{l}\text { Competitive \& } \\
\text { Collaborative }\end{array}$ & \\
\hline
\end{tabular}

adjustments in face of international and local pressures. However, as Rasmussen (2012) points out, it is very difficult to deduct any clear theoretical contribution to explaining competitive advantage.

Our analysis is in line with Campbell and Pedersen's (2007) argument that productive 'institutional complementarities ... also occur in heterogeneous mixtures that blend elements from both political economic types' (p. 231). However, our approach goes beyond Campbell and Pedersen's critique of the $\mathrm{VoC}$ position by providing a conceptual explanation of productive heterogeneity. The VoC literature may have rightly been concerned with problems of contradictions resulting from institutional combinations across the LME-CME divide. By introducing the multilevel selection lens, we offer a way to separate competition and co-ordination/collaboration without disruptive collision.

While ambidexterity and multilevel selection and ambidexterity can explain functionally how competition and collaboration may be combined to further productivity and fair distribution, the extensive Nordic collaborative capacity demands a historical explanation. This points to culture as a powerful engine that, we argue, both helped forge the Nordic way of 'doing politics' and shaped the variety of Nordic capitalism. The relative absence of feudalism, the existence of a free and literate peasantry - especially in Norway and Sweden - and the strong position of community law before the consolidation of the state, together created an important societal basis for broadly inclusive participation in the construction of citizenship and democratic society. In a world ruled by absolute monarchs and feudal landlords, the Swedish, Norwegian, and to some extent, Danish peasants retained their personal, legal and economic freedoms to an extent unheard of in most European countries (Witoszek 1997 in Sørensen and Stråth 1997, pp. 72-90, Witoszek 1998, 2011).

To these structural conditions, we have to add a shared founding tradition, which one of us has called the 'Nordic Pastoral Enlightenment' (Witoszek 1998, 2011). It is largely thanks to the common legacy of the Christian Enlightenment that Nordic modernity has been a relatively socially sustainable formation; one that has honed the ideas of individual dignity and social justice and, simultaneously, recognised the reality of human and environmental limits. The ideal of social cooperation has been consistently replicated in significant cultural texts, from schoolbooks and religious teaching and from national literatures to political visions and the trade union discourse. Influential cultural animateurs like Hans Nielsen Hauge in Norway, Nicolai Grundtvig in Denmark and 
Selma Lagerlöf in Sweden, have all advocated the virtues of teamwork aligned with social emancipation and entrepreneurial value creation (Witoszek and Trägardh 2002, Witoszek 2011, Witoszek and Sørensen 2018). In all the Nordic countries the values of cooperation, altruism, equality and social rights were not merely empty ideas replicated in schoolbooks and political visions. Their bearers literally walked the talk: implementing them in the art of governance and in striving to create responsible business models. The political and business community - and its underlying prosocial mindset - have also functioned as a moral community even after the Christian values propelling it have been diluted and transposed into modern versions of Nordic humanism (Witoszek and Sørensen 2018, pp. 36-58). This humanism is the basis of the unique Nordic 'collaborative capital'. Empirical Underpinnings. We have chosen a range of cases across central societal domains that are designed to indicate thebroad relevance of our perspective. We have started with work life, drawing on Aukrust's classic work of political economy on the front industries model and Moene and Wallerstein's insights into the competitive advantage of wage compression, as well as $\emptyset$ stgård's investigation of 'flexicurity'. We have also covered female work participation, as another hallmark of the Nordic model. The second case - the Norwegian Petroleum sector - is included to illustrate how Nordic engagement in an extractive industry with huge ground rent has been managed productively and equitably, avoiding the resource curse and the gross inequalities that have characterised many petro-economies. The third case - the creative use of CSR demonstrates how Nordic welfare states have been able to ambidextrously 'highjack' a neoliberal agenda to further their ideals and interest in the international economy, here drawing on a comparative study of the Nordic countries.

Our interdisciplinary perspective - based on the opening of political-economic analysis to cultural history and evolutionary theory - allows us to point to the ways in which a shared cultural legacy feeds into ambidextrous, collaborative arrangements in several social domains.

Needless to say, this is by no means a comprehensive analysis of the Nordic model. Rather, it is a pioneering attempt to unwrap the Nordic model through a holistic perspective seldom used in mono-disciplinary studies, but which has the potential to better illuminate both the mainsprings of welfare societies and socially sustainable modernity.

An initial section on 'a culture of trust and pragmatic collaboration' provides a historical basis for the subsequent broad political/institutional economy/economic sociology analysis of contemporary Nordic practices.

Our study is based on several sources, ranging from our own primary analysis, secondary analysis of available economic and social statistics, existing analyses and institutional and legal sources.

Only by making use of this broad span of empirical underpinnings have we been able to substantiate our theoretical argument. We do, however, consider this study to be primarily a conceptual contribution, representing the first set of empirical underpinnings that will have to be expanded in future testing and elaboration.

\section{Cultural Habitus as a Foundation of Welfare Society}

As we have argued above, the foundation of Nordic welfare states lies in cultural texts, rites and 'habits of the heart' which have been consistently replicated in Nordic schoolbooks and formed strong Nordic humanism that remains the centre that holds. The very idea of the state as an inclusive 'people's home' had literary rather than political origins (Witoszek and Sørensen 2018) and fostered a culture of trust and pragmatic negotiation rather than confrontation. That said, teamwork has been a tool to succeed rather than an end in itself. When faced with international competition, 
the Nordics developed ambidextrous, collaborative-competitive combinations both within the productive, sociopolitical and redistributive/caring domains and between them (Figure 1).

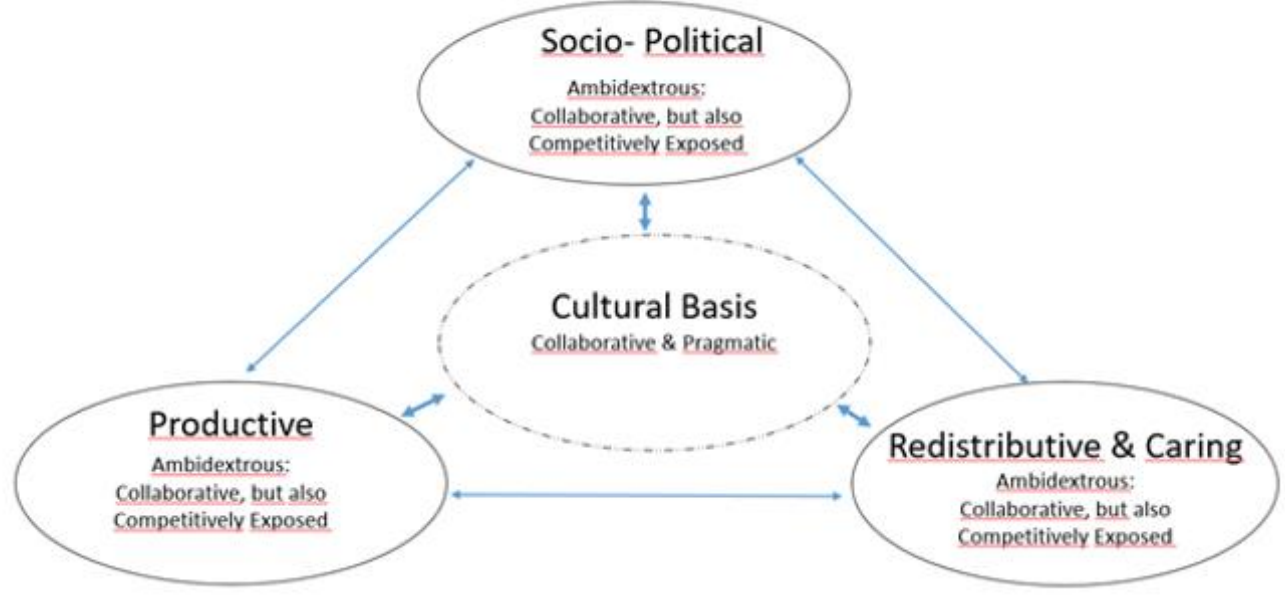

Figure 1: Ambidexterity Within and Across Social Domains

In emphasising the pivotal role of culture in the creation of the welfare society, our analysis takes issue with most economic and political studies that have either disregarded the importance of culture, or treated it as the fifth wheel in a wagon. A classic example is Acemoglu and Robinson's bestseller Why Nations Fail (2012). The authors argue that it is inclusive institutions and not cultural values that make some states crumble and others flourish. This argument is not sufficient to explain the relative success of the Nordic countries. There, a shared cultural founding tradition - rooted in the values of a strong and extended Christian Enlightenment and flaunting a pragmatic Weltanschauung - has been replicated with great fidelity from generation to generation. Highlighting responsibility, trust, cooperation and partnership, this mindset penetrated into political and economic arrangements, entered the discourse of the trade unions and influenced the workings of Nordic institutions. In addition, as has been argued, cooperation and partnership have been a hallmark of gender relations, protected by a woman-friendly welfare state (Trägårdh 2013).

In the following sections, we shall show how an ambidextrous blending of collaborative values with competitive exposure permeates work life, including female participation, resource management illustrated by the Norwegian petroleum economy - and the international diffusion of Nordic values and business practices. In each case, we will show how collaboration is intertwined with pragmatic competitive exposure in ambidextrous modes of organisation.

\section{The Nordic Work Life Model as Part of Ambidextrous Competitiveness}

Several studies of Nordic work-life arrangements have highlighted the productivity and competition enhancing effects of collaborative arrangements, which we see as supporting our ambidexterity perspective. This runs counter to the $\mathrm{VoC}$ thesis of institutional competitiveness stemming from thebenefits that firms derive from operating within a particular set of institutions (Hall and Soskice 2001, Hall and Gingerich 2004, Campbell and Pedersen 2007) 


\section{Front Industries and Wage Compression Models}

In the front industries and the wage compression models coordinated wage bargaining is combined with a competitive advantage in liberal product and service markets.

In the front industries model - in Norway also called the 'Aukrust-model' after the Director of Statistics Norway who formulated it - wage negotiations in the internationally exposed sectors are prioritised, and provide competitive settlements by international wage standards (Aukrust 1977). These settlements are subsequently used as a guiding norm for wage negotiations in domestic sheltered sectors. In other words, ambidextrous orchestration of collaborative wage settlement becomes a tool for international commercial competitiveness.

As pointed out by Bjørnstad and Nymoen (2015), calibration of wages to industrial competitiveness in liberal markets through coordinated negotiations can avoid the difficult trade-off between employment and inflation that would arise under decentralised contestation. By moderating wage demand of productivity in internationally exposed sectors, industry retains profitability, while labour retains high employment.

Through wage compression, centralised wage settlements have also contributed to economic modernisation. As Moene and Wallerstein (2006) have pointed out, on the one hand, centralised wage determination has prevented industries with low levels of productivity from staying in business by paying low wages. On the other, it has also moderated wage demands from workers in industries with high levels of productivity. Hence the effect is to reduce profits in low-productivity firms and increase profits in high-productivity firms, stimulating labour and capital to move from low to high productive activities and thereby increasing the pace of economic development and competitive success in international product and service markets (Agell and Lommerud 1993, Moene and Wallerstein1997).

The combination of collaborative and competitive elements inherent in the front industries and wage compression setups clearly illustrates the ambidexterity of the Nordic model. Admittedly, there is still an ongoing discussion in comparative political economy about the effects of individual factors determining societal fairness and productivity. The scope of this paper does not allow us to review it in detail. Suffice to mention arguments for union density (Rueda and Pontussen 2000), bargaining centralisation and public sector employment (Pontussen et al. 2002) as promoting egalitarian distribution, across the LME-CME divide. Furthermore, Lemieux (2011), Acemoglu and Robinson 2015 and Nijhuis (2017) have all pointed to the role of political and economic institutions in influencing the nature and evolution of inequality. Irrespective of the determining factors, this literature, we argue, is compatible with our ambidexterity hypothesis.

\section{The Flexicurity Model}

The flexicurity model represents an ambidextrous arrangement whereby competitive market dynamics are allowed to play out in a liberal labour market, while redundant employees may rely on coordinated welfare state guarantees, family subsistence and retraining. Again, in line with Campbell and Pedersen (2007), and contrary to the varieties of capitalism literature, we argue that productive institutional complementarities do not arise merely from the homogeneous institutional arrangements of either liberal or coordinated market economies; they also occur in heterogeneous mixtures that blend elements from both political-economic types.

As Uffe Østergård (2011) has pointed out, the system - as practiced in Denmark - contains an unwritten social agreement. The trade unions have accepted short notice for laying off workers in return for an insurance system designed so that the lowest paid workers, from the first day of 
unemployment to up to two years (previously four years) are entitled to benefits equal to $90 \%$ of their former wage. This has enabled a liberal labour market policy where employers can fire and hire at very short notice.

A precondition for the generous benefits is the so-called active labour market policy, whereby all unemployed individuals are obliged to engage in publicly provided upgrading of their qualifications through education and training.

The whole system is mainly collaboratively financed through income taxes and value added. In addition, while the employees pay a small part through membership fees the employers do not contribute to the financing of the unemployment insurance system at all. Yet it stimulates the functioning of a liberal labour market to serve entrepreneurship and high quality products in small and medium businesses (Madsen 2006).

The 'flexicurity' model and its combination of liberal market dynamics with active labour market policy is currently widely embraced also in the other Nordic economies and geared up from its traditional function as an employment facilitator, to take on a stronger role in industrial transformation.

\section{Female Participation in Production}

The competitive advantage of broad female inclusion in the productive economy is also a hallmark of the Nordic model (Teigen and Skjeie 2017, Holst 2018), but once again competitiveness is ambidextrously fused together with collaboration across the LME-CME divide. Female participation in liberal product and service markets has been based on the expansion of the welfare state to include generous public subsidy of parental leave schemes and extensive child care arrangements. To take Norway as an example, all employees are eligible for the parental benefit if they have been gainfully employed. Parents are entitled to a year's salary. Fathers can take three and a half months paid leave. In addition, parents receive child benefit of 970 NOK per month (tax free), from birth to 18. Similar arrangements exist in the other Nordic countries.

The collaborative facilitation of female work participation has clearly paid off. According to the OECD (OECD 2018) in Denmark, Iceland, Norway and Sweden, the growth in women's employment alone accounted for the equivalent of about $10-20 \%$ of average annual GDP per capita growth over the past 40-50 years. The increased value creation and broadening of their tax bases that come with female participation, has boosted Nordic societies' competitiveness and promoted the high welfare levels that characterise them. Along with Switzerland and New Zealand, the Nordics thus stand out as having the highest female participation in the labour market among OECD countries (Figure 2). 


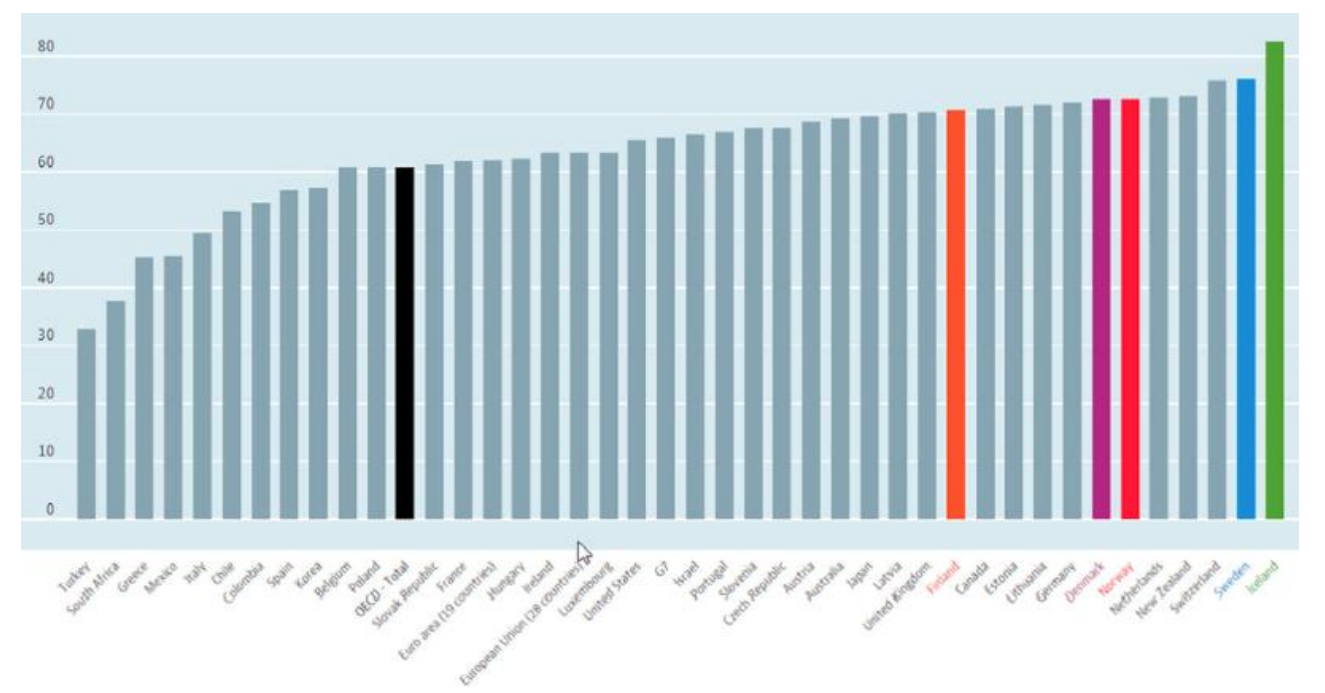

Figure 2: Female Participation in the Work Force in OECD countries (Source OECD - Labour Market Statistics https://data.oecd.org/emp/employment-rate.htm\#indicator-chart)

The build-up of collective welfare arrangements has gone hand in hand with the political promotion of gender equality. Female inclusion in goods- and service production, as well as participation in other societal arenas, has also stimulated gender equality. Alongside Switzerland, the Netherlands and Slovenia, the Nordic countries top the latest UN Gender Equality Index (Table 2).

Table 2. UN gender equality index.

\begin{tabular}{lll}
\hline & Rank order & Score \\
\hline 1 & Switzerland & 0.040 \\
2 & Denmark & 0.041 \\
3 & Netherlands & 0.044 \\
4 & Sweden & 0.048 \\
5 & Iceland & 0.051 \\
6 & Norway & 0.053 \\
6 & Slovenia & 0.053 \\
\hline
\end{tabular}

http://hdr.undp.org/en/data

\section{Norway's Equitable Petroleum Economy}

While work life has been the 'iconic' focus for much of the literature on the Nordic model, theambidextrous combination of competition and collaboration applies to other domains as well, such as the management of natural resources. Norwegian petroleum resources are an interesting case in point. The country has managed to adroitly handle its extraordinary petro-wealth, flaunting collaborative arrangements to cater for the public interest, while securing competitive participation in international petroleum markets, and establishing a leading position in the offshore petroleum industry (Ministry of Petroleum and Energy 2019).

The resources under management are formidable. Petroleum comprises $14 \%$ of GDP, $40 \%$ of exports and $17 \%$ of state income. Nearly a fifth of total investments came from this sector in 2018 . Thus Norway is deeply embedded in the petroleum economy and has been so for over half a century (Figure 3). 


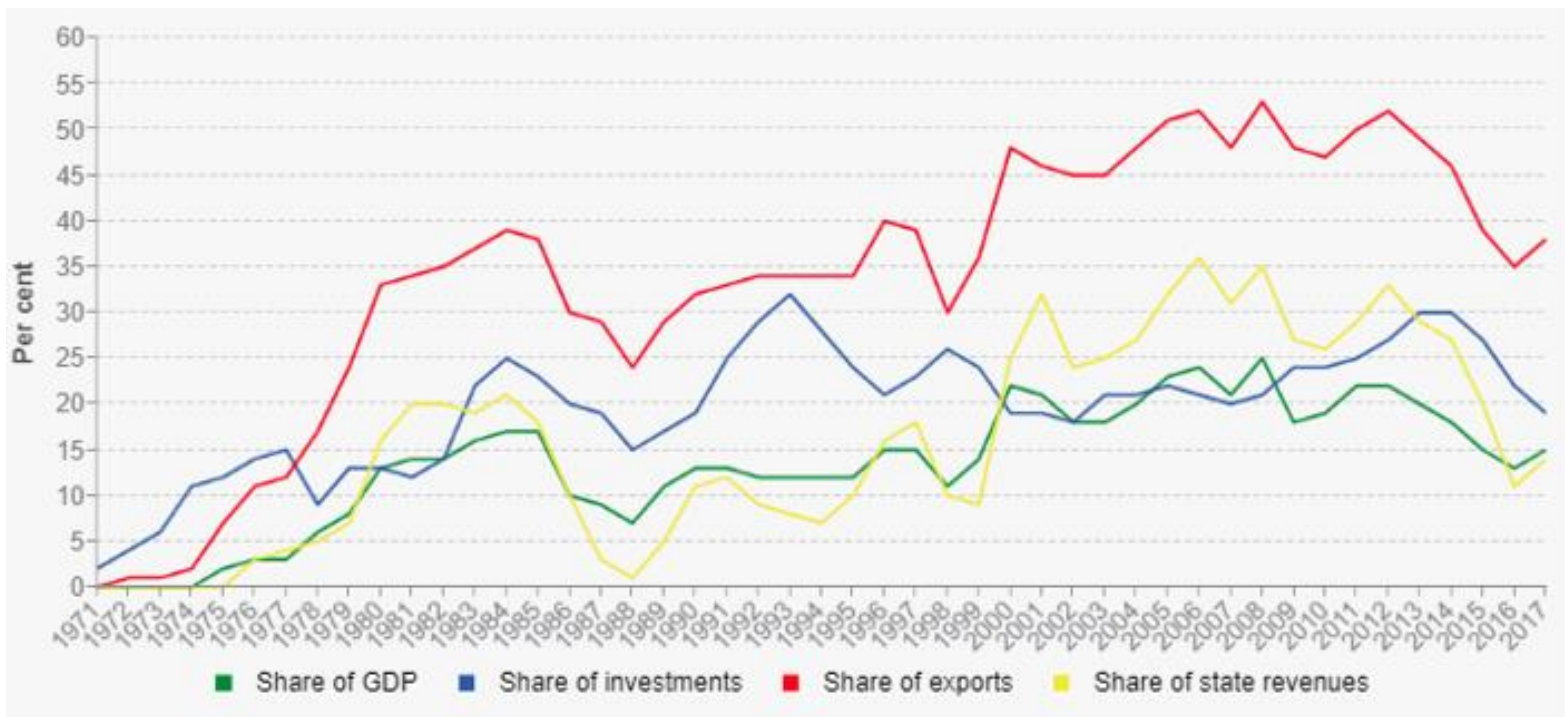

Figure 3. Macroeconomic indicators for the petroleum sector 1971-2017. Source: Norwegian Petroleum (2018).

Norway's petroleum governance is orchestrated through four core regimes: (1) a regulatory regime - to bring petroleum resources under public control and to organise exploration and production efficiently; (2) an industrial regime - to guarantee the build-up of domestic industrial capabilities; (3) a taxation regime - to secure the public interest and (4) a wealth management regime - to safeguard sustainable economic development and fair distribution. Together these regimes constitute an ambidextrous mix of collaborative and competitive elements that taken together transcend the VoC LME and CME divide.

\section{Public Control of Resources and Production}

The Norwegian Government proclaimed sovereignty over the Norwegian continental shelf in May 1963 by establishing that any natural resources on the shelf belonged to the Norwegian state. The country thereby created the basis for a coordinated/collaborative regime to manage petroleum resources with the public interest in mind.

Yet Norway chose to develop its petroleum resources through broad participation of international companies and exposed the actors to global competition, thereby promoting efficiency and productivity through market dynamics. A system of exploration and production licences nevertheless allowed the government to retain extensive control over all phases of petroleum activities (Ministry of Petroleum and Energy 2019).

\section{The Industrial Regime}

Ambidexterity has also characterised the building of the Norwegian petro-industrial regime. A core element has been the establishment of a national petroleum company - Equinor, previously Statoil. The objective of the state ownership of Equinor has been to maintain a knowledgebased, hightechnology company with its main base in Norway (Ministry of Petroleum and Energy 2019).

Public control to secure the national interest has, however, been counterbalanced by competitive exposure. To this effect, the company has gradually been part-privatised and exposed to international competition. Today, Equinor is an international energy company in over 30 countries, and listed on the Oslo and New York stock exchanges, with the Norwegian state owning $67 \%$ of the shares (Government no 2019). 
The Norwegian industrial policy regime has included an ambitious engagement to stimulate a wide supply industry. Through a mix of regulatory and collaborative facilitation and competitive exposure, the Norwegian continental shelf has been developed to become one of the world's largest offshore markets. Drawing on experiences from the shipping and maritime industries, it provides large domestic business opportunities for suppliers and represents an important source of employment (Solbakken and Ryggvik 2018).

In sum, the industrial policy to shape a competitive Norwegian petroleum industry has been successful both due to co-ordination and systematic and increasing competitive exposure, as industrial competencies were developed.

\section{Taxation Regime and Government Cash Flow}

Following the formation of theOPEC cartel in the 1970s, petroleumresources have entailed a large 'cartel rent' or 'ground rent' for investors. Prioritising the public interest, theNorwegian government has taken a strong coordinative approach in the form of a special oil taxation regime that secures collective harvesting fromthe petroleumeconomy. The petroleumtaxation systemadds an additional special tax of $55 \%$ to ordinary company taxation - currently $23 \%$ - and brought in 105 billion NOK in 2018.

In addition, societal interests are further secured by the State's Direct Financial Interest (SDFI) whereby the Norwegian State participates directly in petroleumactivities on the Norwegian continental shelf. Additional income is gleaned from Equinor's dividend and taxation and area fees (Table 3). In addition, the petroleum industry is uniquely exposed to both emissions trading and $\mathrm{CO} 2$ taxation. Nevertheless, the petroleum tax regime is calibrated to attract the interest of international investors that operate under stringent LME commercial terms (Ministry of Petroleum and Energy 2019).

Table 3. The expected net government cash flow from petroleum activities (in billion NOK - nominal values).

\begin{tabular}{lrr} 
& 2017 & 2018 \\
\hline Taxes & 65.0 & 105 \\
Environmental taxes and area fees & 6.1 & 6.9 \\
Net cash flow from SDFI & 88.3 & 97.8 \\
Equinor dividend & 8.4 & 14.5 \\
Net government cash flow & 167.8 & 224.3 \\
\hline
\end{tabular}

Source: Norskpetroleum.no 2018, and Revised National Budget 2018.

\section{The Wealth Management Regime}

To manage the large revenue accumulated on behalf of society, the Norwegian government has developed an advanced wealth management regime. In typically ambidextrous style, the regime combines collaborative securing of the public interest with advanced capital management in nternational financial markets. Furthermore, the regime is also calibrated to manage the impact of the huge revenues on the Norwegian economy. Political collaboration across party divides secures the regime's long-term stability (Engen 2007).

A core element in this management is theGovernment Pension Fund Global (SPU) - popularly known as the 'Oil Fund' - created in 1990 as a fiscal instrument invested abroad in order not to inflate the Norwegian economy. The fund is financed by annual revenues from the government's net cash flow from petroleum activities, as well as the return on the fund's assets. According to a politically 
imposed limitation on the use of the fund to cover current public expenditure (the so-called handlingsregelen) only 3-4\% can be used for annual government expenses. The fund is managed by The Bank of Norway's Investment Management arm (NBIM) on behalf of the Ministry of Finance. In 2018, the Oil Fund had a market value of just over 9 billion NOK, making it the world's largest government fund (NBIM 2019).

Through the Oil Fund Norway has succeeded in transforming a resource base under public ownership into public financial holdings available to the common good but managed according to state of the art financial investment practice. Furthermore, the self-imposed limitation in the annual outtake from the fund serves to limit the potential disadvantages that excessive expenditure might have on Norwegian competitiveness in the international economy (Solbakken and Ryggvik 2018).

Following a parliamentary initiative in 2004 , the Fund has been subject to separate ethical guidelines. The SPU also exercises active influence through its ownership of individual companies to press for good governance and the upholding of decent social and environmental standards.

\section{Norway's Petroleum Economy in International Comparison}

The complementary, collaborative and competitive architecture of the Norwegian petroleum regime is exceptional with respect to combining social sustainability with economic efficiency. Countries like Venezuela, Nigeria, Angola, and to some extent Russia, Iran and Iraq, have failed to transform their petroleum endowments into high value creating economies, while Kuwait, and to some degree, Saudi Arabia have not had their petroleum wealth trickle down as equitably to the population (Figure 4).

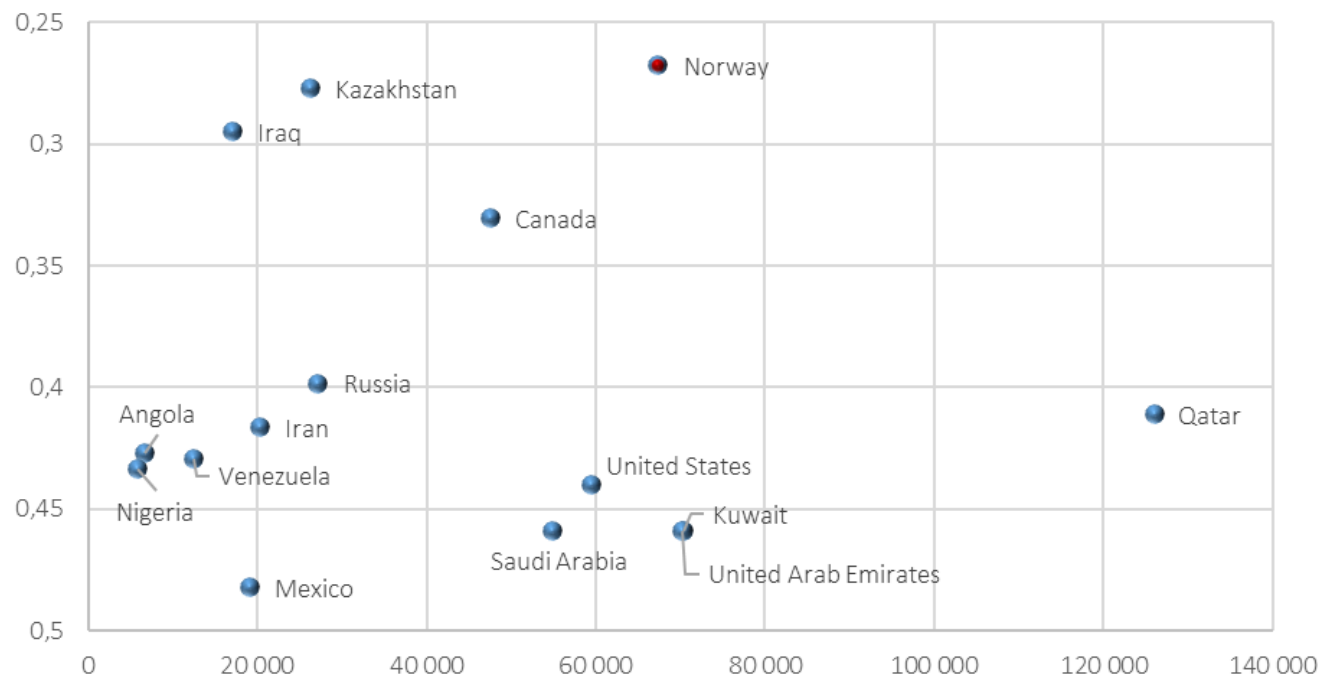

Figure 4: GDP per Capita and Equality.

Source: GDP average as provided by World Bank 2017, CIA 1993-2017 and IMF 2017

(https://en.wikipedia.org/wiki/List_of countries by GDP (PPP)_per_capita), GINI average as provided by World Bank (2006-2015) and CIA (2006-2014) (https://en.wikipedia.org/wiki/List of countries by income equality). Departing from calculations made by the World Inequality Database, Kuwait and the United Arab Emirates are estimated to be on the same level as Saudi Arabia, whose level of income inequality we gathered from the World Bank (2013).

To sum up, the ambidextrous melange of collaboratively coordinated and competitive institutional arrangements of the Norwegian petroleum economy defies any clear categorisation into coordinated or liberal market economy typology. In pursuit of industrial development, productive efficiency and distributive fairness, the country has pragmatically adopted a mixed economy approach, where competitive and collaborative/coordinated elements have been applied at 
different levels and in different domains and thereby prevented from colliding. It is precisely the combination of coordinating institutions that further public interest, with the commercial exposure which advances competitiveness, that has given Norway its unique position with high scores on productivity and fairness.

'Civilising' Global Capitalism: Aligning CSR and the Welfare State While manoeuvring as small players in the difficult terrain of the international economy, one of the creative initiatives of the Nordic countries has been their ability to combine their strong welfare-state tradition with neoliberal Corporate Social Responsibility or CSR. The CSR tradition, we recall, originated in the neoliberal, Anglo- American context, as a result of strong civic pressure. Yet it emphasizes corporate discretion, voluntarism and market-based policy solutions (Sadler and Lloyd 2009). In the Nordic welfare-state tradition - based on universal rights and duties, extensive state engagement in the economy and negotiated agreements to regulate labour relationships - one might think adopting CSR would be a tall order. In fact, the Nordics count among the CSR champions. In line with their ambidextrous flexibility, the Nordic countries have found a way to use CSR to their advantage. We argue that their eager adoption of CSR illustrates Nordic pragmatism and ability to ambidextrously mix liberalist and coordinated approaches.

The attraction CSR holds to the Nordic welfare states lies in their endorsement of CSR's fundamental goals and values. The CSR agenda, with its emphasis on fostering socially and environmentally responsible business practices, resonates well with the ethos of the Nordic welfare states. For example, the CSR idea of the triple bottom line - ensuring balanced development of financial, social and environmental elements - chimes with Nordic welfare-state policies, whereby business development is regulated and/or negotiated to take into account distributive and ecological concerns. At first glance one might, therefore, see the Nordic states' CSR engagement as an attempt to complement their welfare-state traditions with new policy tools.

At the level of means, however, the two traditions differ. As opposed to the advanced welfare state model, CSR relies primarily on voluntary business initiatives. CSR is traditionally industry driven and delegates key welfare issues to business discretion. This voluntary approach is in stark contrast to advanced welfare states' traditions favouring negotiated agreements and strong regulation to control corporate conduct.

Nevertheless, a comparative study of Nordic CSR (Midttun et al. 2015) shows how Sweden and Norway in particular, but also the other Nordic countries, have pragmatically aligned CSR with Nordic political engagement for a social and environmental upgrading of the global economy. Nordic firms operating in international markets have been under strong domestic pressure from vibrant civil society groups and public opinion to uphold social and environmental standards abroad. Similar pressure is also channeled onto Nordic governments. Yet as small nations, the Nordics wield limited bargaining power. Against this background, actively backing CSR in international business practice has become a good second best strategy, an attempt to fill the regulatory gap with higher social and environmental standards in the global market economy. CSR has become an attractive opportunity to expand Nordic influence beyond the reach of traditional welfare measures. Furthermore externalising CSR to the international economy has avoided conflicts with traditional welfare practice at home. 


\section{Partnered Governance}

What is interesting about the Nordic adoption of CSR is its innovative thrust. In line with the Nordics' tradition for pragmatic ambidexterity, CSR in the Nordic context has become a joint project promoted by industry and the state alike, a partnered governance for economic upgrading (Midttun 2008). The Nordic governments have engaged in CSR to advance policy agendas alongside Nordic firms that hold front-runner positions in the global economy. This formula seems to have worked. Studies of Nordic companies' CSR performance show that the Nordics - alongside with Swiss and followed by the UK and the Dutch - have been the top scorers (Midttun et al. 2006; Gjølberg 2013) (Figure 5).

The broad compact between government, business and civil society in order to socially and environmentally upgrade the international economy, which has also been highlighted by Strand and Freeman (2015), entails once again an ambidextrous mix of collaborative and competitive elements, supported by governments and designed to enhance both industrial and social and environmental performance. Needless to say, the Nordic civil society organisations (CSOs) have played a crucial role in this process. While the ongoing social pressure invites the risk of non-compliance, it also increases the opportunity to capitalise on compliance in commercial quality-branding strategies. This ambidextrous melange of government, industry and civil society engagement for the social and environmental enhancement of the international economy has strengthened the Nordics' capacity to expand elements of good governance beyond their national borders in line with the externalization strategy where CSR is relegated to the international arena. By doing so under the CSR label, they have legitimately transcended the territorial limitations of the nation-state and thereby gained far greater regulatory influence.

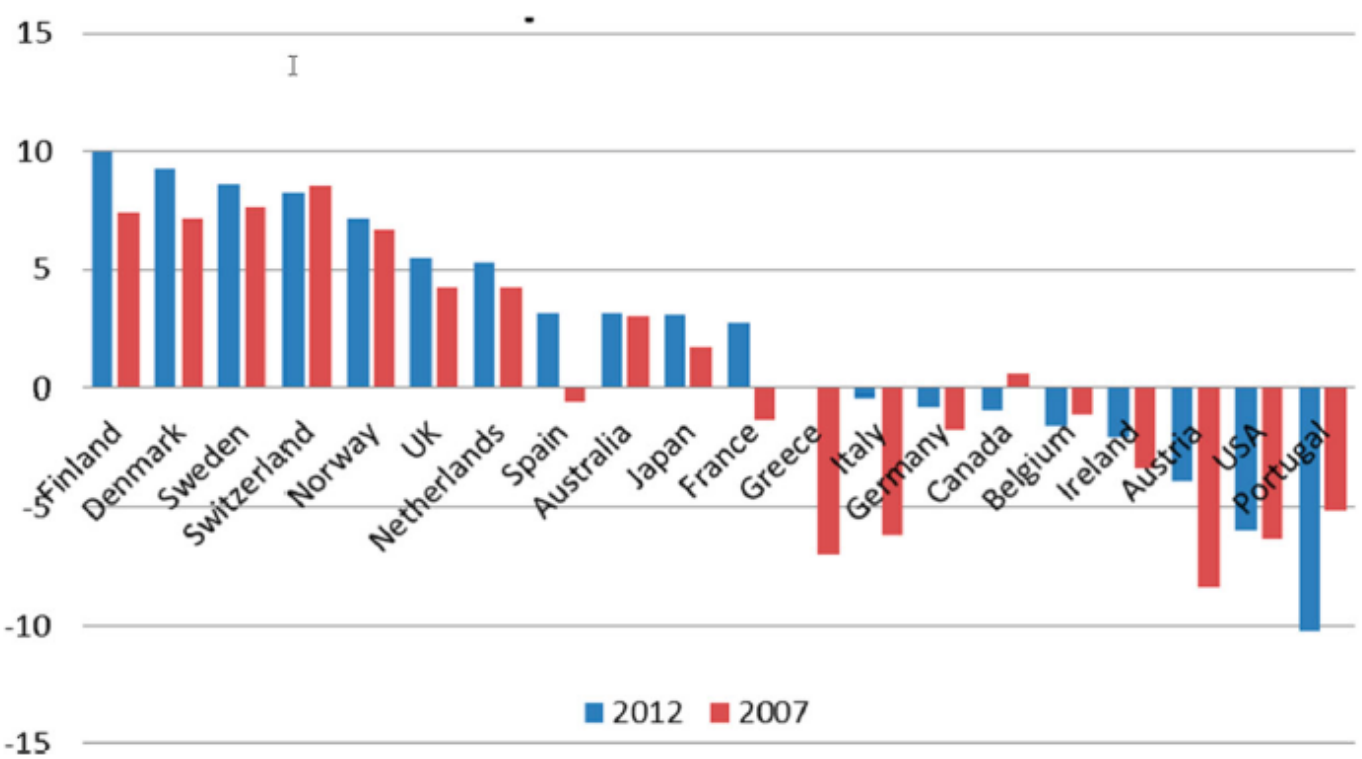

Figure 5. Cross-national CSR performance in 2007 and 2012.

Source: Gjølberg (2013).

That said, the Nordic engagement in CSR and partnered governance is not unique. It has been inspired by models from other front-runner countries, such as the UK, the Netherlands and Switzerland, and then tailored to the Nordic context. This context, with its tradition of social dialogue and strong egalitarian values, has often proven to be fertile ground for the further stimulus 
of partnered governance arrangements. The Extractive Industries Transparency Initiative (EITI) and the Ethical Trade Initiative are good examples. Both originated in Britain - under Tony Blair's 'New Left' agenda - and both were subsequently eagerly adopted by the Nordic countries in a partnered governance mode, amply demonstrating their capacity for ambidextrous combination of competitive and collaborative engagement.

To sum up, when it comes to CSR, the Nordics have once again proven their capacity to bridge the liberalist and coordinated market agenda. The externalisation of CSR to the international economy has involved an ambidextrous amalgamation of conventional welfare-state policies and liberalist corporate-led engagement across the LME-CME divide. In addition, the Nordics have warmly embraced innovative partnered strategies, where government, civil society and companies work together for a fairer and more inclusive economy.

\section{Concluding Remarks: Nordic Resilience Through Ambidexterity}

This paper has shown how the Nordics have managed to combine high productivity, welfare and fair income and wealth distribution by pursuing ambidextrous strategies. We have illustrated how they meld collaboration and competition in work life, resource management and international relations. We have also argued that this ambidexterity collides with a more 'monistic' institutional description of the Nordics in the VoC literature. A core element in the monistic approach is the notion of institutional complementarity (Magnin 2018). Such complementarity implies that institutional structures reinforce each other within a common 'institutional paradigm'. To go back to the VoC typologies, institutions either mutually reinforce a liberal market regime or a coordinated market one.

However, by drawing on multilevel selection and organisational theory we have demonstrated how completion and collaboration may productively co-exist within the same socio-economic system, but at the same time operate at different levels, and in different domains. For instance, the coordinated appropriation of super profits into a public fund to serve the public interest, in the case of the Norwegian petroleum economy, has been combined with highly competitive financial asset management in international capital markets. The seeming contradictory, and - in Kolakowski's (1963) terms - inconsistent 'logic' of the ambidextrous Nordic model provides a broader spectrum of options to deal with the difficult task of achieving both fair distribution and high productivity.

While our focus in this article may have a production bias, we in no way discard the importance of demand side management as a core part of the Nordic model. The Nordics have been ardent supporters of Keynesian demand side politics. They have pushed counter-cyclical expansionary fiscal policy and added a repertoire of monetary policies to strengthen its impact, in line with mainstream economic thinking. In fact, we would argue that ambidexterity and multilevel selection remain highly relevant to the demand side. The Nordics have typically created a large public sector with extended services to the population. This feature lends itself to economic stabilisation and counter-cyclical demand side management. The Nordic countries have done so on the basis of on collaborative values and traditions which allow them to pursue more ambitious collective service provision than most other societies. However, the licence to maintain these extended services depends on a commitment to efficiency and direct or indirect competitive exposure. 


\section{The Resilience of the Nordic Model}

The question remains: can the Nordic countries uphold their balance of competition and cooperation and reproduce it in an age of cultural collisions, the digital economy, the fragmentation ofwork-life and intrusive EU regulation? And isn't the flagrant competitiveness of the neoliberal economy eroding teamwork, prosociality, trust and cooperation? Admittedly, the harsh climate of their (socio-political, institutional and economic) environment has affected the basic traits of Nordic societies, such as relatively egalitarian income distribution. While the Nordics, along with most other industrial nations, saw an extensive drop in inequality from the 1950s and into the early 1990s, the trend over the most recent decades has reversed (Figure 6). The 'golden age' of social-democratic values went further towards equality and lasted longer in the Nordic countries than elsewhere. While the Nordics saw the top $1 \%$ richest getting as little as $5 \%$ of the share of national income, in the US this never dipped below $10.4 \%$ (in 1976). The top $1 \%$ share in UK was, on average, $7 \%$ between 1960 and 1980 .

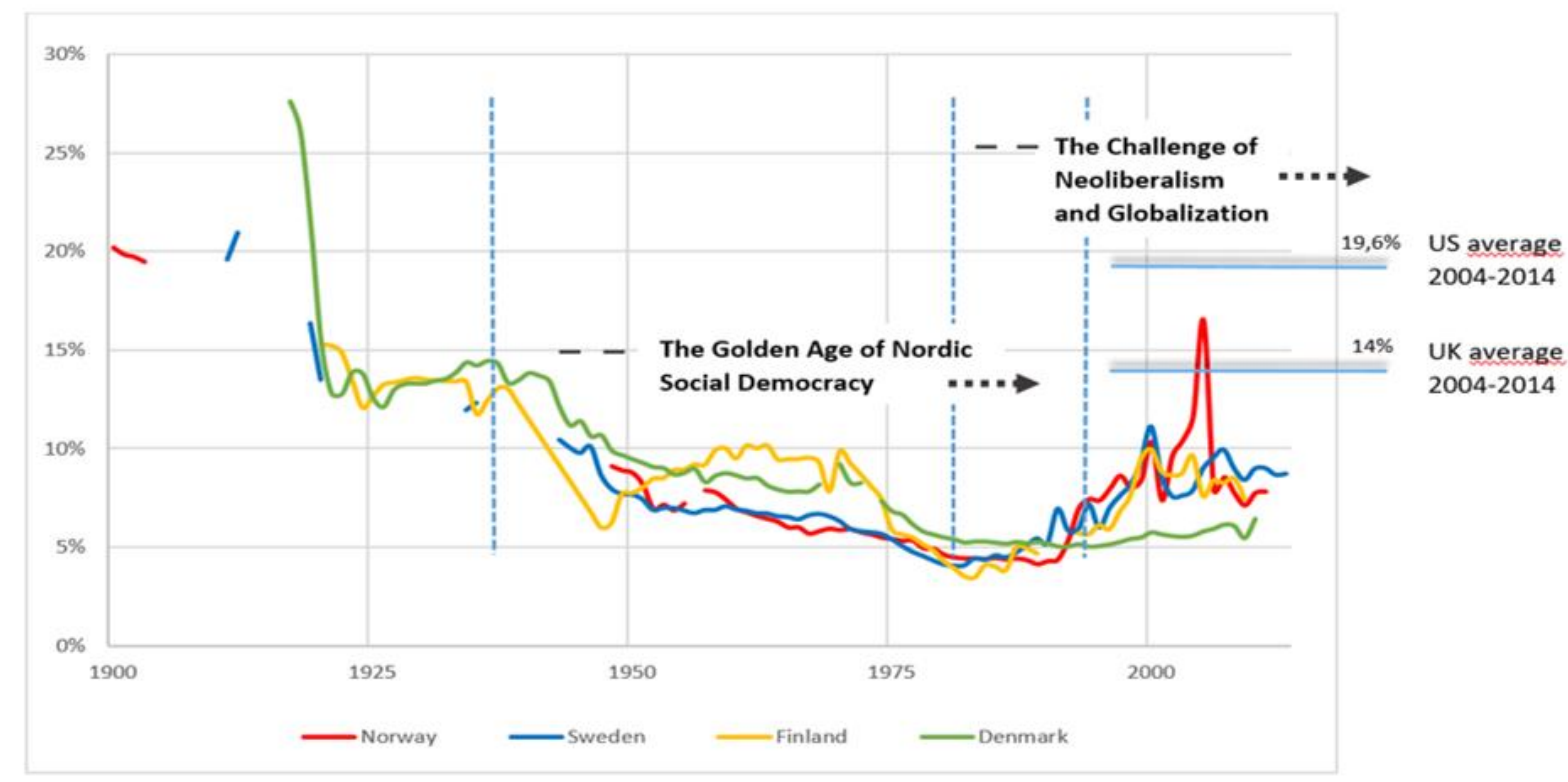

Figure 6: Income Inequality

Source: World Inequality Database (wid.world) 2018

The recent rise in inequality has been smaller and started from a lower level in the Nordics than in most other countries. The rise has been lowest in Denmark where the $1 \%$ increased its income on average by only $5.9 \%$ between 2004 and 2010. It has been somewhat higher in Norway and Finland with respectively 8.3\% (2004-11) and 8.3\% (2004-9) and higher still in Sweden (an 8.9\% average 2004-13.). However, inequality in the US and UK has risen to far higher levels - respectively $20 \%$ and $14 \%$ - in the same period. Nevertheless, the divergence among the Nordic countries as well as between the USA and UK points to the limits of a simple CME - LME distinction. In fact, Baccaro and Pontusson (2016) see the diversity of late industrial (post-Fordist) trajectories among CMEs, and LMEs as a distinctive feature of the current political economy ${ }^{4}$.

\footnotetext{
4 Baccaro and Pontussen also point to Thelen's (2014) distinction between two different CME trajectories: dualization, exemplified by Germany and flexibilization exemplified by Sweden and Denmark as promising advances in diversifying the $\mathrm{VoC}$ approach.
} 
That said, a strong and egalitarian social-democratic culture has not prevented increasing challenges from the right-wing populism. However, what is notable is that, although the rise of nationalistpopulist parties - emerging in Denmark in the 1970s, in Norway in the 1980s, in Finland in the 1990s, and in the 2010s in Sweden - is indisputable, as late as 2018 these parties have functioned less as emblems of new and aggressively nationalist Nordicity, and more as correctives to the original, founding tradition. Its replicators - encapsulated in narratives in education, the media and political visions - keep highlighting welfare, solidarity, trust and social emancipation. In order to remain successful, even the most 'reactionary' movements have had to take on board major elements of the Nordic habitus (Fukuyama 2011), as the Sweden Democrats' party programme reveals:

.... The Sweden Democrats are a social conservative party with a nationalist basic view, which regards value conservatism and the maintenance of a solidaristic welfare model as the most important tools in the construction of the good society.

On the whole, while extensive institutional changes have taken place, the resilience of Nordic collaborative-competitive ambidexterity remains its defining characteristic. This, we argue, is due to the fact that the Nordic countries have been able to build a more extensive social contract and deeper levels of collective engagement and responsibility than many other societies. It is thanks to their shared cultural values, perpetuated among others by the trade unions, that they are able to come up with institutional and strategic responses to new competitive challenges. These responses embody collaborative mobilisation and solidarity at one level and competitive edge at another. At their best, the Nordics combine teamwork with pragmatism; an amalgam which yields relatively high resilience under stress.

Thus, though it is hazardous to predict the future of the Nordic countries, their strong culture of collaboration warrants cautious optimism. As the second decade of the twenty-first century draws to a close, Nordic ambidexterity continues to imbue the Nordic model with the ability to reincarnate into ever new forms. Norwegian, Danish, Swedish and Finnish cultures carry community-oriented virtues, while the flexible combination of competition and cooperation ensures they are able to confidently meet and overcome new challenges. 


\section{Literature}

Acemoglu, D. and Robinson, J.A., 2012. Why nations fail. London: Profile Books.

Acemoglu, D. and Robinson, J.A. 2015. The rise and decline of general laws of capitalism. Journal of economic perspectives, 29 (1), 3-28.

Agell, J. and Lommerud, K., 1993. Egalitarianism and growth. The Scandinavian journal of economics, 95 (4), 559-570.

Aukrust, O. 1977. Inflation in the open economy: a Norwegian model. Reprinted from: L.B. Krause and W.S. Sålant, eds. Worldwide inflation: theory and recent experience. Washington, DC:

Brookings.

Baccaro, L. and Pontusson, J., 2016. Rethinking comparative political economy. Politics \& society, 44 (2), 175-207.

Barth, E., Moene, K.O., and Willumsen, F., 2015. The Scandinavian model - an interpretation. Journal of public economics, 117, 17-29.

Bjørnstad, R. and Nymoen, R. 2015. Frontfagsmodellen i fortid, nåtid og framtid. Report no 1-2015. Fafo og Samfunnsøkonomisk analyse AS. Oslo.

Campbell, J. and Pedersen, O.K., 2007. Institutional competitiveness in the global economy: Denmark, the United States, and the varieties of capitalism. Regulation \& governance, 1 (3), 230246.

Council of Economic Advisers. 2018. The opportunity costs of socialism. Report from the executive office of the president of the United States. October.

Engen, O.A.H. 2007. The development of the Norwegian Petroleum Innovation System: a historical overview. TIK working paper on innovation studies no. 20070605, University of Oslo.

Fukuyama, F., 2011. The origins of political order. New York, NY: Farrar, Straus and Giroux.

Gjølberg, M., 2013. Nordic companies - global pioneers in CSR. In: A. Midttun, ed. CSR and beyond: a Nordic perspective.

Oslo: Cappelen Damm, 287-304.

Government.no. 2019. Available from: https://www.regjeringen.no/en/topics/energy/stateownership-in-the-energysector/part-owned-company/id2353247/ [Accessed 1 May 2019]. Hall, P.A. and Gingerich, D.W. 2004. Varieties of capitalism and institutional complementarities in the macroeconomy: an empirical analysis. Discussion paper 04/5. Cologne: Max Planck Institute for the Study of Societies.

Hall, P.A. and Soskice, D., eds., 2001. Varieties of capitalism: the institutional foundations of comparative advantage. Oxford: Oxford University Press.

Holst, C., 2018. Scandinavian feminism and gender partnership. In: N. Witoszek and A. Midttun, eds. Sustainable modernity: the Nordic model and beyond. London: Routledge, 102-118.

Hull Kristensen, P. and Lilja, K., eds., 2011. Nordic capitalisms and globalisation. Oxford: Oxford University Press.

Kolakowski, L., 1963. In praise of inconsistency. Dissent, 11, 2, 201-209.

Krugman, P. 2015. Something not rotten in Denmark. Op-ed in The New York Times, October 19. Lemieux, T., 2011. Wage inequality: a comparative perspective. Australian bulletin of labour, 37, 1, $2-32$. 
Madsen, P.K., 2006. Flexicurity: a new perspectiv on labour markets and welfare states in Europe. Paper for the DG EMPL seminar on Flexicurity, Brussels May 18. CARMA Centre for Labour market Research, Aalborg University, 1-19

Magnin, E., 2018. Varieties of capitalism and sustainable development: institutional complementarity dynamics or radical change in the hierarchy of institutions? Journal of economic issues, 52 (4), 1143-1158.

Midttun, A., 2008. Partnered governance: aligning corporate responsibility and public policy in the global economy. Corporate governance: the international journal of business in society, 8 (4), 406418.

Midttun, A., Gautesen, K., and Gjølberg, M., 2006. The political economy of CSR in Western Europe. Corporate governance: the international journal of business in society, 6 (4), 369-385.

Midttun, A., et al., 2015. Public policies for corporate social responsibility in four Nordic countries. Business \& society, 54 (4), 464-500.

Miller, T., Kim, A., and Roberts, J., 2018. 2018 Index of economic freedom. Heritage Foundation. Available from: https:// www.heritage.org/index/pdf/2018/book/index_2018.pdf.

Ministry of Petroleum and Energy. 2019. Norway's petroleum history. Available from: https://www.norskpetroleum.no/en/framework/norways-petroleum-history/ [Accessed 1 May 2019].

Mjøset, L., ed., 2011. The Nordic varieties of capitalism. Comparative social research. Bingley: Emerald Group.

Moene, K.O. and Wallerstein, M., 1997. Pay inequality. Journal of labor economics, 15 (3), 403-431. Moene, K.O. and Wallerstein, M., 2006. 'The Scandinavian model and economic development': special report. New York, NY: World Bank Institute.

NBIM - Bank of Norway Investment Management. 2019. Available from: https://www.nbim.no/en/ [Accessed 1 May 2019].

Nijhuis, D.O., 2017. Explaining postwar wage compression. Labor history, 58 (5), 587-610.

Norwegian Petrolrum, 2018. Available from: https://www.norskpetroleum.no/en/ [Accessed 7

December 2018].

OECD, 2018. Is the last mile the longest? Paris: OECD. Available from: https://read.oecd-

ilibrary.org/social-issues-migration-health/is-the-last-mile-the-longest-economic-gains-from-genderequality-in-nordic-countries_9789264300040-en \#page5.

O'Reilly, C.A. and Tushman, M.L., 2004. The ambidextrous organization. Harvard business review, April, 71-84

Østergård, U., 2011. Current challenges to Nordic labor policy: the Danish 'flexicurity model'. In: A. Midttun and N. Witoszek, eds. 2011 'The Nordic model: is it sustainable and exportable?' Report. BI Norwegian Business School and University of Oslo.

Pontusson, J., Rueda, D., and Way, C.R., 2002. Comparative political economy of wage distribution: the role of partisanship and labour market institutions. British journal of political science, 32, 350383.

Rasmussen, E., 2012. Review of 'Nordic capitalisms and globalisation'. Journal of industrial relations, 54 (5), 709-711.

Rueda, D. and Pontussen, J., 2000. Wage inequality and varieties of capitalism. World politics, 52, 350-383.

Sadler, D. and Lloyd, S., 2009. Neo-liberalising corporate social responsibility: a political economy of corporate citizenship. Geoforum, 40, 613-622. 
Schmitter, P.C. and Streeck, W. 1982. The organisation of business interests: a research design to study the associative action of business in the advanced industrial societies of Western Europe. Discussion Paper LMP. International Institute of Management.

Schwartz, H., 2013. Book review: the Nordic varieties of capitalism. Acta sociologica, 56 (2), 193-195. Sejersted, F., 2011. The age of social democracy: Norway and Sweden in the twentieth century. Princeton, NJ: Princeton University Press.

Solbakken, M.S. and Ryggvik, h. 2018. "Norsk oljehistorie” Store Nordiske leksikon. Oslo. Available from: https://snl.no/ Norsk_oljehistorie.

Sørensen, $\varnothing$. and Stråth, B., eds., 1997. The cultural construction of Norden. Oslo: Scandinavian University Press.

Stiglitz, J.E., 2015. Leaders and followers: perspectives on the Nordic model and the economics of innovation. Journal of public economics, 127 (C), 3-16.

Strand, R. and Freeman, R., 2015. Scandinavian cooperative advantage: the theory and practice of stakeholder engagement in Scandinavia. Journal of Business Ethics, 127 (1), 65-85.

Teigen, M., and Skjeie, H., 2017. Chapter 5 'The Nordic gender equality model. In: O. Knutsen, ed. The Nordic models in political science. Challenged but still viable? Bergen: Fagbokforlaget, 125-148. Thelen, K., 2014. Varieties of liberalization and the new politics of social solidarity. New York, NY: Cambridge University Press.

Trägårdh, L., 2013. The historical incubators of trust in Sweden: from the rule of blood to the rule of law. In: M. Reuter, et al., eds. Trust and organizations: confidence across borders. New York, NY: Palgrave Macmillan, 181-203.

Wilson, D.S. and Wilson, E.O., 2007. Rethinking the theoretical foundation of sociobiology. The quarterly review of biology, 82, 327-348.

Witoszek, N., 1997. Fugitives from Utopia: the Scandinavian enlightenment reconsidered. In: $\varnothing$. Sørensen and B. Stråth, eds. The cultural construction of Norden. Oslo: Scandinavian Universiy Press. Witoszek, N. and Sørensen, $\varnothing$. 2018. Nordic humanism as a diver of welfare society. In: N. Witoszek and A. Midttun, eds. Sustainable modernity: the Nordic model and beyond. London: Routledge, 3658. 